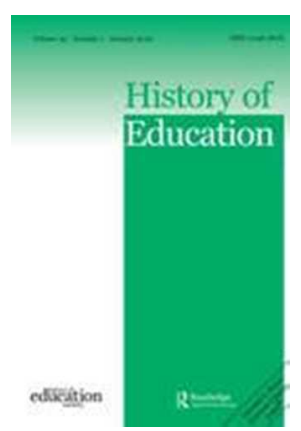

\title{
Enriching the Historiography of Religious Education: Insights from Oral Life History
}

\begin{tabular}{|r|l|}
\hline Journal: & History of Education \\
\hline Manuscript ID & THED-2016-0051.R1 \\
\hline Manuscript Type: & Article \\
\hline Keywords: & $\begin{array}{l}\text { Oral Life History, Methodology, professional identity and practice, } \\
\text { curriculum development, professional organisation }\end{array}$ \\
\hline
\end{tabular}

\section{SCHOLARONE ${ }^{\text {m }}$ \\ Manuscripts}




\section{Enriching the Historiography of Religious Education: Insights from Oral Life History}

Authorship:

1) Jonathan Doney (corresponding author)

Graduate School of Education

University of Exeter

St Luke's Campus

Heavitree Road

Exeter

EX1 2LU

Email: J.Doney@exeter.ac.uk

Telephone: 07762061165

2) Stephen G. Parker

Institute of Education

University of Worcester

Henwick Road

Worcester

WR2 6AJ

Email: s.parker@worc.ac.uk

Telephone: 01905542165

3) Rob Freathy

Graduate School of Education

University of Exeter

St Luke's Campus

Heavitree Road

Exeter

EX1 2LU

Email: R.J.K.Freathy@,exeter.ac.uk

Telephone: 01392724818 
This article seeks to exemplify the extent to which oral life history research can enrich existing historiographies of English Religious Education (RE). Findings are reported from interviews undertaken with a sample of key informants involved in designing and/or implementing significant curriculum changes in RE in the 1960s and 1970s. The interviews provided insights into personal narratives and biographies that have been marginal to, or excluded from, the historical record. Thematic analysis of the oral life histories opened a window into the world of $R E$, specifically in relation to professional identity and practice, curriculum development, and professional organizations, thereby exposing the operational dynamics of RE at an (inter)personal and organizational level. The findings are framed by a series of methodological reflections. Overall, oral life histories are shown to be capable of revealing that which was previously hidden and which can be confirmed and contrasted with knowledge gleaned from primary documentary sources.

Keywords: Oral life history; methodology; professional identity and practice; curriculum development; professional organisation.

\section{Biographical approaches in the historiography of Religious Education}

It is widely held that a new chapter in the history of English Religious Education (RE) began in the 1960s and 1970s, with the period being associated with radical changes in the aims, methods and content of RE in fully state-maintained schools (without a religious character) in England. ${ }^{1}$ In theory at least, there was a move away from a form of Christian confessionalism (whereby children were nurtured in and encouraged to adopt the beliefs and practices of the Christian faith), towards a 'postconfessional', phenomenological, multi-faith approach ${ }^{2}$ (whereby children became acquainted 'with some basic facts about other men's [sic.] religions and the social and cultural contexts within which they find expression'), ${ }^{3}$ with the aim of enabling pupils to 'gain an authentic understanding of religion' ${ }^{4}$ and to 'increase tolerance and understanding, the widening of the pupil's horizons, as well as deepening his

\footnotetext{
${ }^{1}$ Rob Freathy and Stephen Parker, 'The necessity of historical inquiry in educational research: The case of Religious Education', British Journal of Religious Education 32, no. 3 (2010): 229-243; Stephen Parker and Rob Freathy, 'Context, Complexity and Contestation: Birmingham's Agreed Syllabuses for Religious Education since the 1970s.' Journal of Beliefs and Values 32, no. 2 (2011): 247-262; Stephen Parker and Rob Freathy, 'Ethnic Diversity, Christian Hegemony and the Emergence of Multi-faith Religious Education in the 1970s.' History of Education 41, no. 3 (2011): 381-404; Rob Freathy and Stephen Parker, 'Freedom From Religious Beliefs: Humanists and Religious Education in England in the 1960s and 1970s', in Religious Education and Freedom of Religion and Belief, eds. Stephen Parker, Rob Freathy and Leslie Francis (Oxford: Peter Lang, 2012): 7-27; Rob Freathy and Stephen Parker, 'Secularists, Humanists and religious education: religious crisis and curriculum change in England, 1963-1975.' History of Education 42, no. 2 (2013): 222-256.

${ }^{2}$ Philip Barnes, 'Working Paper 36, Christian Confessionalism and phenomenological religious education', Journal of Education and Christian Belief 6, no. 1 (2002): 61-77.

${ }^{3}$ Durham, The fourth R: The Report of the Commission on Religious Education in Schools (London: National Society/SPCK, 1970): §264.

${ }^{4}$ City of Birmingham Education Committee, Agreed Syllabus for Religious Education (Birmingham: City of Birmingham Education Committee, 1975): 9-10.
} 
understanding of man [sic.] and the world' ${ }^{5}$ The existing historiography frequently exemplifies these changes in terms of the influence of the Schools Council Working Paper 36 and the 1975 Birmingham Agreed Syllabus of Religious Instruction. ${ }^{6}$

However, much of this existing historiography is predicated on the analysis of documentary material originating in the period under scrutiny. Based on this, a history of RE has developed that foregrounds, what David Labaree has called, the rhetorical and formal curriculum. This is the curriculum proposed by policymakers and academics in speeches, reports and textbooks, and demonstrated by school policy documents and schemes of work, ${ }^{7}$ as opposed to the curriculum-in-use or received curriculum which is the content teachers actually deliver, and the content that students actually learn. ${ }^{8}$ Our earlier archival research, in an attempt to uncover the history of RE that is hidden behind the published record, analysed unpublished source material from relevant archives, and contextualized these in the wider political and educational scene. ${ }^{9}$ Even so, these explorations still told us more about the politics and procedures lying behind the rhetorical and formal curriculum than they did about curriculum in practice. Further, they told us little about the historical actors who implemented the rhetorical and formal curriculum.

The research reported here differs from our own prior research in two significant ways. Firstly, it does not rely principally upon primary documentary sources, except in so far as our prior acquaintance with such sources has shaped the current project and our interpretation of the oral life history data. Secondly, drawing us nearer to practice by considering what it meant to be a participant in the history that has already been told, the research focuses on the biographies of those who conceived of, and implemented, the RE curriculum changes of the 1960s and 1970s. Andrea Jacobs and colleagues argue that such perspectives are 'a vital ... part of our social, political and cultural history', ${ }^{10}$ yet such personal narratives have been frequently undervalued within the history of education. Whilst there are some examples of this changing (Ina ter Avest's recent work, for example, foregrounds the importance of (auto)biographical reflection in relation to the development of RE), there are a number of important issues of relevance to this rehabilitation of personal narrative raised by, for example, Annette Kuhn in her distinctive and insightful introduction to memory as history. ${ }^{11}$

\footnotetext{
${ }^{5}$ Schools Council, Schools Council Working Paper 36: Religious Education in Secondary Schools (London: Methuen Educational, 1971): 63.

${ }^{6}$ Schools Council, Working Paper 36; City of Birmingham Education Committee, Agreed Syllabus for Religious Education; City of Birmingham Education Committee, Living together: A teachers' handbook of suggestions for religious education (Birmingham: City of Birmingham Education Committee, 1975).

${ }^{7}$ D.F. Labaree, 'The chronic failure of curriculum reform', Education Week 18, no. 36 (1999): 42-45.

${ }^{8}$ See Parker and Freathy, 'Context, Complexity and Contestation'.

${ }^{9}$ For example: Freathy and Parker, 'The Necessity of Historical Inquiry', 'Secularists, Humanists and Religious Education'; Parker and Freathy, 'Ethnic Diversity, Christian Hegemony'; Rob Freathy, Stephen Parker and Jonathan Doney. 'Raiders of the Lost Archives: Searching for the Hidden History of Religious Education in England', in History, Remembrance and Religious Education, eds. S. G. Parker, R. Freathy and L. J. Francis (Oxford: Peter Lang, 2014): 105-137.

${ }^{10}$ Andrea Jacobs, Camilla Leach and Stephanie Spencer, 'Learning lives and alumni voices', Oxford Review of Education 36, no. 2 (2010): 219.

${ }^{11}$ Ina ter Avest, On the Edge: (Auto)biography and Pedagogical Theories on Religious Education (Rotterdam; Boston: SensePublishers, 2012); Annette Kuhn, Family Secrets: Acts of Memory and Imagination (London: Verso, 1995).
} 
Whilst, in the existing historiography of RE, the theories of some 'high profile academics' have been recorded and discussed, ${ }^{12}$ the relevance of their personal narratives and biographies has largely been overlooked; prior research has explored the personal stories of teachers in general without specifically focusing on RE specialists. ${ }^{13}$ The voices of other types of historical actors, for example, RE Advisers, teaching practitioners, and other educational professionals, who were involved in the design and implementation of curricula change, are absent from the historiography, implying an unwarranted lesser status and import to their historical perspectives.

An exception to this lacuna is found in Terence Copley's book, Teaching Religion. Copley includes three brief biographical sketches from individuals 'starting out in religious education' in 1935, 1968 and 1995. Whilst these sketches are interesting enough, and draw attention to the existence of such narratives, they are appended without analysis or interpretation. ${ }^{14}$ This lack of exploration regarding their contribution to the wider narrative combined with the positioning of the sketches as appendices, demonstrates a marginalization of the voices of their writers. Such a marginalization is indicative of the general neglect of personal narratives within the historiography of RE.

In order to explore the way in which such narratives can enrich the historiography of education, we argue in the first part of this article that such a personal narrative approach can be fruitful in developing and enriching the educational history of RE, describing how we implemented the approach. In the second part we present our findings, through the discussion of interviews that we have undertaken, and in third part, we reflect on the methodological issues arising, stressing specific areas of contention, and arguing that this approach is as rigorous as other historiographical approaches. Thus, we identify ways in which this approach augments knowledge of events by drawing upon the memories of those involved in a critically reconstructed way. This process has the potential to reveal matters that have been marginal to, or excluded from, the historical record, providing insight into areas of personal and professional life other types of source cannot, and confirming and contrasting with knowledge gleaned from primary published and unpublished documentary sources. We argue that the collected personal, religious and professional narrative accounts represented by our interviews enrich understandings of the changes occurring within RE over a sustained period, adding a human dimension to the

\footnotetext{
${ }^{12}$ For example, Bates on John Hull (Denis Bates, 'John Hull: A Critical Appreciation', in Education, Religion and Society: Essays in honour of John M. Hull, eds. D. Bates, G. Durka \& F. Schweitzer (Abingdon: Routledge, 2006): 6-32); Barnes on Ninian Smart (L.P. Barnes, 'Ninian Smart at the Phenomenological Approach to Religious Education', Religion 30 (2000): 315-32; L.P. Barnes, 2001, 'What is wrong with the Phenomenological approach to Religious Education', Religious Education 96, no. 4 (2001): 445-61); Teece on John Hick (Geoff Teece, A religious approach to religious education: the implications of John Hick's religious interpretation of religion for religious education (Unpublished $\mathrm{PhD}$ thesis, University of Birmingham, 2010).

${ }^{13}$ For example: D. Clandinin, and F. Connelly, 'Narrative, experience and the study of the curriculum', Cambridge Journal of Education 20, no. 3 (1990): 241-53; Ivor Goodson, Studying Teachers' Lives (London: Routledge, 1992); Ivor Goodson and Pat Sikes, Life History Research in Educational Settings (Maidenhead: Open University Press, 2001); K. Weiler and S. Middleton, (eds), Telling Women's Lives: Narrative Inquiries in the History of Women's Education (Buckingham: Open University Press, 1999); Richard J. Altenbaugh, 'Oral History American Teachers and a Social History of Schooling: an emerging agenda', Cambridge Journal of Education, 27 (1997): 313-330.

${ }^{14}$ Terence Copley, Teaching Religion (Exeter: Exeter University Press, 2008); Rob Freathy, 'Book Review. Teaching Religion: Sixty Years of Religious Education in England and Wales', History of Education 39, no. 4 (2010): 567-570.
} 
historiography. ${ }^{15}$ Moreover, we suggest that by being attentive to such personal narratives, new data of potential relevance to a wide range of issues in the history of RE, curriculum and wider educational history, and other areas of history, including religious history, can be unearthed. Not least, these may contribute to ongoing parallel research on the professionalization of RE teachers, specifically in relation to the initial and continuing professional development, professional (self-)organisation and professional politics, and professional knowledge of RE teachers. ${ }^{16}$

\section{Oral life history methodology}

Our study set out to record a series of interviews with a sample of key informants, to analyse their previously ignored oral testimonies in order to emancipate the voices of historical actors who were involved in developments in RE through the 1960s and 1970s, and thus to open up this neglected field and enrich the historiography of RE. We did so by gathering personal narratives from professionals and practitioners, who were as much witnesses to change as they were agents of it, and whose life histories have been deliberately or accidentally silenced within the existing historiography. We expected much to be revealed that had hitherto been marginal to, or excluded from, the historical record, not least how changes in RE theory, policy and practice were enacted and experienced at a (inter-)personal level by the protagonists involved.

In pursuit of the enquiry 'what were the life-histories of RE professionals and practitioners?' we were able to explore the potential of differing stakeholder groups to offer insights which can enrich the existing historiography through such questions as: Why did people choose to become involved in RE and what did they hope to achieve by doing so? How were their personal theologies, ideologies and confessions formed, how did they develop, and of what influence were they upon their professional values and practices? To what extent were aspirations for their practice facilitated or challenged by the changing models of RE during the period? How far did RE influence those who entered the profession out of a sense of Christian vocation? Do these oral life histories indicate the emergence of a new kind of professional identity during this period?

Having decided to undertake such interviews, we discovered that within the literature there is some confusion over the terms 'life history' and 'oral history'. ${ }^{17}$ There are similarities between the approaches, with both attempting to emancipate hidden and marginalized voices that have been excluded from the historiography. ${ }^{18}$ Both sometimes, but not always (as will be explained below),

\footnotetext{
${ }^{15}$ M. Jolly, 'Oral history, life history, life writing: the logic of convergence', in Memory, Narrative and Histories: Critical Debates, New Trajectories, working papers on memory, narrative and history (no. 1), ed. C. Dawson (Brighton: Centre for Research in Memory, Narrative and Histories, 2012): 59.

${ }^{16}$ S. G. Parker, R. Freathy, and J. Doney, 'The Professionalisation of Non-Denominational Religious Education in England: politics, organisation and knowledge', Journal of Beliefs and Values 37, no.2 (2016): 201-238; R. Freathy, S. G. Parker, F. Schweitzer and H. Simojoki, 'Conceptualizing and Researching the Professionalization of Religious Education Teachers: Historical and International Perspectives', British Journal of Religious Education 38, no. 2 (2016): 114-129; R. Freathy, S. G. Parker, F. Schweitzer and H. Simojoki, 'Towards international comparative research on the professionalization of Religious Education', Journal of Beliefs and Values 35, no. 2 (2014): 225-241.

${ }^{17}$ For example, R. Dhunpath, 'Life history methodology: "narradigm" regained', Qualitative Studies in Education 13, no. 5 (2000): 543-51; V.R. Yow, Recording Oral History: A Guide for the Humanities and Social Sciences (Walnut Creek, CA; AltaMira Press, 2005): 3-4.

${ }^{18}$ See, for example, Paul Thompson, The Voice of the Past: Oral History (Oxford: Oxford University Press, 2000).
} 
involve the collection of personal narrative accounts through interviews. For this reason, the terms life history and oral history have at times been used interchangeably, militating against the possibility of devising clearly delineated and mutually exclusive definitions. However, it is possible to discern some differences between the approaches in terms of their contrasting historical origins and general methodological orientations. Oral history, which emerged during the 1960s and 1970s, ${ }^{19}$ and has been particularly associated with the voices of the working classes and of women, ${ }^{20}$ is perceived by some as an instrument of social change. ${ }^{21}$

On the other hand, life history research, which arose from the documentary movement of the 1920s and 1930 s and its attempt to capture the experience of a variety of social groups, ${ }^{22}$ tends to place less emphasis on criticality and social change, and more on enriching the wider historiography through the inclusion of individual, marginalized, voices. Valerie Yow suggests that life history is 'an account by an individual of his or her life that is recorded in some way ... for another person who edits and presents the account'. ${ }^{23}$ Methodologically, a variety of tools are available in recording the 'text' of life history, including personal diaries, structured autobiographical writing, recorded monologues and interviews. In contrast, oral history concentrates solely on oral accounts, generally collected through interviews.

Aware of these debates, and the sometimes permeable distinctions between these differing terms, we have rejected the epithet 'oral history', which might suggest an emphasis on social change which is not present in our work. Likewise, we have avoided using the term 'life history' alone, without qualification, because it might suggest a variety of tools that we have not used. Instead, in line with our employment of recorded oral interviews which have been edited and presented by the researchers rather than the interviewees, we have adopted the term 'oral life history' to differentiate this approach from others. ${ }^{24} \mathrm{In}$ adopting the term oral life history, we align ourselves with those who call for methodological clarity in the field.

Sample and method

${ }^{19}$ For example, J. McLeod and R. Thomson, Researching social change: qualitative approaches (London; Thousand Oaks, Calif.: SAGE, 2009); Joanna Bornat, Timescapes Methods Guides Series 2012: Guide No. 12: Oral History and Qualitative Research (London: ESRC Qualitative Longitudinal Initiative, 2012).

${ }^{20}$ For example, Luisa Passerini, 'Work Ideology and Consensus under Italian Fascism', History Workshop 8 (1979): 82-108; 'A Memory for Women's History: Problems of Method and Interpretation', Social Science History 16, no. 4 (1992): 669-692; Penny Summerfield, Reconstructing Women's Wartime Lives: discourse and subjectivity in oral histories of the Second World War (Manchester: Manchester University Press, 1998); S.C. Williams, 'The Problem of Belief: The Place of Oral History in the Study of Popular Religion', Oral History (Autumn 1996): 27-34; Stephen Parker, Faith on the Home Front: aspects of church life and popular religion in Birmingham, 1939-1945 (Oxford: Peter Lang, 2005); J. Bornat and H. Diamond, 'Women's History and Oral History: developments and debates', Women's History Review 16, no. 1 (2007): 19-39.

${ }^{21}$ For this discussion, see Thompson, 'The Voice of the Past', Chapter 1.

22 Jolly, 'Oral History, Life History', 48.

${ }^{23}$ Yow, 'Recording Oral History', 225 (our emphasis).

${ }^{24}$ For a further delineation of the types of interview in oral and life history see S. Gluck, 'What's so Special about Women? Women's Oral History', Frontiers: A Journal of Women Studies 2, no. 2 (Summer 1977): 3-17. For use of the term oral life history, see K.A. Henderson, 'An oral life history perspective on the containers in which American farm women experienced leisure', Leisure Studies 9, no. 2 (1990): 121-133. 
We undertook eighteen oral life history interviews with academics, practitioners and professionals involved in designing and implementing curriculum development in RE, including School Inspectors from both Her Majesty's Inspectorate (HMI; up to 1992) and the Office for Standards in Education (Ofsted; from 1992), Local Education Authority and Diocesan advisors, area workers for various groups, teachers, and teacher trainers. It is important to note that many of these individuals fulfilled more than one role during their careers and that their memories of specific periods may have been coloured by these later professional experiences. Rather than undertake a systematic, detailed analysis of the history of RE from the perspective of individuals within only one of these groups, which would have been possible and would have yielded particular insights, we chose to interview a diversity of individuals representative of some of the range of stakeholders involved in RE policy and/or practice in the period under scrutiny.

The formation and implementation of the 1975 Birmingham Agreed Syllabus of Religious Instruction ${ }^{25}$ represents an historical event spanning the early and middle years of the 1970s, which saw contrasting stakeholders come together to participate in what became a well-known (and hence memorable) milestone in the history of English multi-faith RE. ${ }^{26}$ Drawing on our knowledge of the existing historiography, key informants were identified who would provide insight into the events surrounding this syllabus, and who would be well placed to evaluate its short- and long-term influence on the nature and purpose of RE. These informants would also provide knowledge of the local context of Birmingham in the 1970s and shed light on the network of personal, professional and social influences, which shaped it. Through a process of snowball sampling, whereby one interviewee recommends further potential participants, ${ }^{27}$ we broadened our interviewee cohort to reflect wider parameters both geographically (from the Midlands of England to particular key national informants) and temporally (extended to the 1980s as some of the changes at the official level took some time to be implemented at the classroom level).

A semi-structured interview schedule was used with all participants to explore: early personal experiences (highlighting religious background and the development of personal worldviews); personal experiences of RE; and interviewees' academic backgrounds and training (including motivation for career choices). Further questions facilitated a detailed exploration of their professional biographies in relation to RE (particularly in discrete local contexts); the nature of their roles; how the subject changed over the period of the interviewees' experiences; and their involvement with specific professional groups and networks. Finally, interviewees were prompted to explore their reflections on current issues in RE from an historical perspective and were asked to highlight any particular issues of which they felt it important for the research team to be aware.

\footnotetext{
${ }^{25}$ Birmingham City Education Committee, 'Birmingham Agreed Syllabus for Religious Instruction'.

${ }^{26}$ See Freathy, et al., 'Raiders of the Lost Archive'; Jonathan Doney, 'That would be an ecumenical matter': Contextualizing the adoption of World Religions Teaching in English Religious Education through a systematic operationalization of Foucault's historical methods. (Unpublished PhD thesis, Exeter University, 2015).

${ }^{27}$ For example, D.D. Heckathorn, 'Respondent-driven sampling: a new approach to the study of hidden populations', Social Problems 44, no. 2 (2002): 174-99; K. Farquarson, 'A different kind of snowball: identifying key policymakers', International Journal of Social Research Methodology 8, no. 4 (2005): 345-53.
} 
In line with ethical guidance from The Oral History Society, ${ }^{28}$ we agree that it is good practice to secure informed consent from participants at the point of arranging interviews, with clear explanations of: the purpose of the interview, the goals of the project, the use to which the recorded interview would be put, and the safeguards in place to preserve participant privacy. Consequently, we began each recording with a summary of these explanations, and a reminder that interviewees were free to refuse to answer any of the questions and/or withdraw their consent at any point. ${ }^{29}$

Interviews each lasted approximately two hours, although one or two were significantly longer. It was evident that some interviewees had undertaken a great deal of preparation for their interview, often gathering documents or other 'artefacts', whilst others followed up their interview with communiqués that expanded on their answers or corrected their perceived omissions in the recorded interviews. This is not to suggest that all narratives are linear and rehearsed; sometimes the asking of one question within an interview prompted a series of revelatory steps whereby the interviewee constructs an answer. Neither the absence or presence of such preparation and follow up was preferred; 'gut reaction' responses were not viewed as more or less valid or important than those that are carefully rehearsed.

\section{Transcription and extract selection}

Transcription, and the re-creation of the interview into a 'text', ${ }^{30}$ is problematic, not only because of issues of accuracy, ${ }^{31}$ but because non-verbal cues such as inflection, hesitation, and the volume of speech-all of which provide clues important to rhetorical analysis - are lost in the transcription process. ${ }^{32}$ Thus we chose not to analyse written verbatim transcriptions of the interviews, rather we maintained the "performance as well as the script [so] we can still visit the moment of production' ${ }^{33}$ Accordingly, we undertook an aural analysis, which entailed listening to interviews, and noting themes and topics of discussion, together with their position in the recording for ease of relocation.

Stephanie Taylor discusses the matter of extract selection in some detail, stating that 'the basis for their selection is often unclear'. ${ }^{34}$ In order to address this, Taylor calls writers to consider the extent of extracts and to explain the basis on which they are included. ${ }^{35}$ In what follows, extracts have been carefully selected in order to illustrate the type of information exposed by oral life history, recognizing 'that there may not be any single succinct extract that summarizes the complexity of larger findings and

28 Oral History Society, 'Is your oral history legal and ethical?: Practical Steps'. URL: http://www.ohs.org.uk/ethics.php\#ethical-considerations (last accessed 8/05/2014).

${ }^{29}$ For example, Rob Freathy and Stephen Parker, 'Introduction', in History, Remembrance and Religious Education, eds. S. G. Parker, R. Freathy and L. J. Francis (Oxford: Peter Lang, 2014) pp. 1-19. ${ }^{30}$ Jolly, 'Oral History, Life History', 54.

${ }^{31}$ For example, G. Gibbs, Analyzing Qualitative Data (London: Sage, 2007).

${ }^{32}$ For example: J.M. Atkinson and J. Heritage, 'Transcript notation: structures of social action: studies in conversation analysis'. Aphasiology 13, no. 4 (1999): 243-9; U. Flick, An Introduction to Qualitative Research, 4th ed., (London: Sage, 2009): 300-2.

${ }^{33}$ Gardner and Cunningham, 'Oral History and Teachers' Professional Practice', 340; see also Bornat, Timescapes Methods Guides. See also: Alessandro Portelli, 'The Peculiarities of Oral History', History Workshop Journal 12 (1981): 96-107.

${ }^{34}$ Stephanie Taylor, "One participant said ...": the implications of quotations from biographical talk', Qualitative Research 12, no. 4 (2012): 388-401, 389.

${ }^{35}$ Taylor, 'One participant said ...', 399. 
patterns in the data, and that data are distinct from interpretations and claims'. ${ }^{36}$ Only after such decisions were made was the transcription of extracts carried out.

\section{The ethics and implications of anonymization}

The issue of anonymity is inextricably linked to the question of what motivates people to become participants in such research as ours. ${ }^{37}$ Martin Hammersley highlights that many interviewees perceive interviews as a chance to 'tell their story', ${ }^{38}$ and therefore are enthusiastic about being involved, ${ }^{39}$ even seeing interviews as 'cathartic, providing a therapeutic and liberating experience' ${ }^{40}$ There is a risk that such enthusiasm overrides concerns regarding privacy and 'protection' of the 'subject', ${ }^{41}$ which gives rise to an ethical tension between the widely accepted imperative to 'protect the identity of those who participate in research ${ }^{42}$ and the appropriate recognition of the interviewees' authorial role. Further, Hammersley highlights that participant enthusiasm may also skew perceptions about how interview data might be used, for example, assuming that researchers are interested primarily in experiences and feelings, when in fact discursive constructions and rhetorical strategies are the research focus. ${ }^{43}$ Rather than striving for anonymity, which is relatively difficult to achieve where research participants are drawn from a small, easily identifiable population, and even more so where the likely audience and the research participants in some way overlap, ${ }^{44}$ we chose to emphasize the safeguarding of participant privacy. $^{45}$

Failure to recognize the authorial role of the interviewee has negative repercussions, especially in terms of interviewee identity, researcher-rooted editorial control, and in negotiating the meaning of what is said. ${ }^{46}$ By retaining the participant's real name, their contribution is linked with a specific person with a specific identity, located in a specific spatio-temporal context. Removing their name breaks that link, and with it the link to the related contextual information. Ultimately, the removal of any socio-political and other contextual information impoverishes the data. ${ }^{47} \mathrm{We}$ are persuaded by Caitríona Nì Laoire, whose emphasis shifts away from anonymization of data towards the provision of a safe space within which her participants' narratives can be shared, together with a negotiated agreement between the

\footnotetext{
${ }^{36}$ Taylor, 'One participant said ...', 399.

${ }^{37}$ Tom Clark, 'On 'being researched': why do people engage with qualitative research?', Qualitative Research 10, no. 4 (2010): 399-419.

${ }^{38}$ Martyn Hammersley, 'On the Ethics of Interviewing for Discourse Analysis', Qualitative Research 14, no.5, (2013): 532.

${ }^{39}$ Clark, 'On 'Being Researched'.

${ }^{40}$ Cate Watson, 'Unreliable narrators? 'Inconsistency' (and some inconstancy) in interviews', Qualitative Research 6, no. 3 (2006): 367-84: 368.

${ }^{41}$ For example, Clark, 'On 'Being Researched'.

${ }^{42}$ Andrew Clark, Working Paper: Anonymising Research Data (London: ESRC Series, Real Life Methods, Working Paper, 2006): 4; see also BERA, Ethical Guidelines for Educational Research (London: BERA, 2011): 7.

${ }^{43}$ Hammersley, 'On the Ethics of Interviewing'.

${ }^{44}$ Susan Malone, 'Ethics at home: informed consent in your own backyard', International Journal of Qualitative Studies in Education 16, no. 6 (2003): 797-815; see also Clark, Working Paper: Anonymising Research Data.

${ }^{45}$ Kenneth Howe and Michelle Moses, 'Ethics in Educational Research', Review of Research in Education 24 (1999): 21-59.

${ }^{46}$ Caitríona Ní Laoire, 'To name or not to name: reflections on the use of anonymity in an oral archive of migrant life narratives', Social \& Cultural Geography 8, no. 3 (2007): 373-90.

${ }^{47}$ Clarke, 'Working Paper: Anonymising Research Data'.
} 
parties. ${ }^{48}$ Further, where a narrative belongs to an identifiable individual, it is more 'difficult' for the researcher to redact it. Any attempts made by the researcher to speak for the participants, even well intentioned acts of emancipation, can become acts of oppression. ${ }^{49}$ To perform such acts of misguided ventriloquism or, as bel hooks puts it, engaging in a 'form of colonization', ${ }^{50}$ runs the risk of further marginalising the silenced. Ultimately, researchers cannot speak for others, 'we can only tell our story about their lives'. 51

\section{Findings: a window into another world}

Initial aural analysis of the interviews exposed a series of themes within and across interviews that indicate an agenda for furthering understandings of the development of RE across the period under scrutiny; any one (or more, in combination) could be the focus of subsequent, more specialized, research. Themes were identified on the basis of qualitative rather than quantitative criteria. Some were arrived at deductively against a list of motifs identified in our previous work, which had informed the design of the interview schedule. Other themes emerged that had previously been hidden or marginalized in the existing historiography. By tabulating themes across all interviews, we devised the following taxonomy:

Table 1

\begin{tabular}{|c|c|}
\hline Main theme & Sub-themes \\
\hline $\begin{array}{l}\text { Personal Experience and its } \\
\text { effect on professional } \\
\text { identity and practice }\end{array}$ & $\begin{array}{l}\text { - Personal (non-)religious identity } \\
\circ \text { Childhood religious formation } \\
\text { - Encounters with difference/'religious other' } \\
\text { - Disciplinary background and academic career } \\
\circ \text { Development of, and influences upon, personal worldviews and } \\
\text { theories of RE } \\
\text { - Vocational motivation }\end{array}$ \\
\hline Professional Development & $\begin{array}{l}\text { Experiences of teacher training } \\
\circ \text { Experience of continuing professional development provision and } \\
\text { providers } \\
\circ \text { Experiences of career mobility } \\
\end{array}$ \\
\hline Professional Organizations & $\begin{array}{l}\text { Reflections on experiences of, and involvement with, professional } \\
\text { organizations } \\
\circ \text { Perceptions of the relationships between professional organizations }\end{array}$ \\
\hline Curriculum Development & $\begin{array}{l}\text { Experiences of the formation and (non-)implementation of Agreed } \\
\text { Syllabuses. } \\
\circ \text { Influences upon, and examples of, curriculum innovation. } \\
\circ \text { Involvement in the formation and/or implementation of new } \\
\text { pedagogical approaches. } \\
\circ \quad \text { Perceptions of changes and continuities in RE curriculum content and }\end{array}$ \\
\hline
\end{tabular}

${ }^{48}$ Nì Laoire, 'To name or not to name', 374 \& 386.

${ }^{49}$ Gert Biesta, 'A New Logic of Emancipation: The Methodology of Jacques Ranciere', Educational Theory 60, no. 1 (2010): 39-59.

${ }^{50}$ bel hooks 1990, cited by Val Gillies and Pam Alldred, 'The Ethics of Intention: Research as a Political Tool'. In Ethics in Qualitative Research, eds. M. Mauther, M. Birch, J. Jessop and J. Miller (London: SAGE, 2002): 32-52, 40.

${ }^{51}$ Griffin 1996, cited by Alldred and Gillies, 'Eliciting research accounts', 41. 
${ }^{52}$ See, for example, Parker, Freathy and Doney, 'The Professionalisation of Non-Denominational Religious Education in England'; Freathy, Parker, Schweitzer and Simojoki, 'Conceptualizing and Researching the Professionalization of Religious Education Teachers'; and Freathy, Parker, Schweitzer and Simojoki, 'Towards international comparative research on the professionalization of Religious Education'.

${ }^{53}$ For example: Adrian Bell, 'Agreed Syllabuses of Religious Education', in Social Histories of the Secondary Curriculum: Subjects for Study, ed. I. Goodson (London: Falmer Press, 1985); G. Parsons, 'There and back again? Religion and the 1944 and 1988 Education Acts', in The growth of religious diversity: Britain from 1945. Vol. 2, Issues, ed. G. Parsons (London: Routledge, 1994): 161-98; L.P. Barnes, 'Developing a new post-liberal paradigm for British religious education', Journal of Beliefs \& Values 28, no. 1 (2007): 17-32; L.P. Barnes and A. Wright, 'Romanticism, representations of religion and critical religious education', British Journal of Religious Education 28, no. 1 (2006): 65-77. 
of RE provided by oral life history reveals a rather different vista; here we highlight four particular facets.

Firstly we discovered that, even though the relationship between worldview/faith position and professional practice is regularly articulated and re-articulated in scholarly literature (for instance, in this period, the teacher's prior commitment was problematized in favour of a posited neutrality in the classroom) ${ }^{54}$ each individual had to negotiate these complex intersections for themselves, carving out their own path. They each articulated a subtly different kind of narrative, with different metaphors, which recount different spiritual/professional journeys. However, of the eighteen interviewees, eight were at one point or another ordained to Christian ministry, whilst a further four had undertaken significant ministry roles without ordination (encompassing overseas mission, Christian youth work and leading Bible study groups). All but one expressed a commitment to Christianity of some hue, even if no longer active, with the other describing a strong commitment to Buddhism. In this regard, our oral life history data can enrich understandings of the broader religious history of England and specifically that pertaining to the nature and extent of de-Christianization and religious pluralization. ${ }^{55}$ Our data reveal, for example, some of the challenges presented by these wider socio-cultural processes to religious educators in particular, not least how they had to reconceive the relationship between their personal worldview/faith positions and the conceptions of multi-faith RE that were emerging. With regard to prior religious motivation, for instance, some interviewees were reticent, whilst others were more open and explicit about the role that their faith position played in their professional biographies and development:

'I taught science and maths, moved on after a year. I felt called by God to switch tracks to become [an] RE specialist ... Christian motivation led [me] to consider [the] contribution that I could make as an RE specialist. ${ }^{56}$

Particularly for those who had been in church leadership, whether ordained or lay, the need to reconcile different understandings of ministry in relation to RE had also been necessary:

'in the early days of teaching I was committed to transmitting my faith; I

hadn't sorted out the difference between Sunday school and community school teaching. ${ }^{57}$

Similarly, some interviewees, whilst willing to disclose that there were religious motivations to their decisions, were reluctant to use the language of vocation. One suggested that he was brought back to the faith of his upbringing through the practice of 'teaching religion, justifying it, showing it was not a waste of time'. 58

\footnotetext{
${ }^{54}$ See E. Hulmes, Commitment and Neutrality in Religious Education (London: Geoffrey Chapman, 1979).

${ }^{55}$ Freathy and Parker, 'Secularists, Humanists and religious education'; Jeffrey Cox, 'Review: The Local Church and Generational Change in Birmingham, 1945-2000, by Ian Jones (Rochester, N.Y., Boydell Press, 2012)', The Journal of Interdisciplinary History Vol. 44, No. 3, (2014): 412-414.

${ }^{56}$ Interview with Peter Lefroy-Owen, 29 May 2012.

${ }^{57}$ Interview with Julie Grove, 7 May 2010.

${ }^{58}$ Interview with John Hull, 26 March 2010.
} 
Likewise, the oral life history interviews allowed us to understand something of how these individual practitioners responded to the 'religious other'. This facet featured - to some extent - in all eighteen interviews; interviewees particularly considered their encounters with religious difference in relation to the ways in which they conceived of their practice as RE professionals. One interviewee described at length his own experience of Christmas in Bethlehem amongst Palestinians whilst on National Service, and explicitly linked this to his professional practice, expressing his aspiration that his pupils had a proper regard for those of another worldview. ${ }^{59}$ Another (a committed Christian) described her startling first encounter with an artefact from Hinduism and how this experience related to her own faith position:

'I was confronted by images and ideas that I found very difficult to handle ... [there] was an enormous shrine figure of Ganesh and I was horrified by it. I thought I couldn't do this! On reflection I thought that my faith was the only right one, and I couldn't understand what people saw in other religions ... When we started trialling the [teaching resources], the first thing we [saw] was Ganesh... I learnt more about that image it fitted with my journey. ${ }^{90}$

For others, their first encounter with the religious other was in the classroom:

'I can remember the first Hindu, we didn't have a Muslim ... We did have a Hindu boy and I remember saying it would be lovely if you could share with us something of your faith, your religion ... I realised later on that he tried to tell $u s$ the story of Rama and Sita, although his grasp of it was very limited, and the children found it very strange. ${ }^{61}$

This extract also highlights the importance of analysis that extends beyond simple content. Here, the rhetorical structures deployed in describing the event highlight the polarization between 'them' and 'us' ${ }^{62}$ Similarly, the extract foregrounds the teacher's perception of his role as arbiter of the accuracy of the retelling of the story; it demonstrates a tension between the teacher's conception of his own authoritative subject-specific content knowledge, ${ }^{63}$ and the personal knowledge presented by the pupil as an adherent of the faith community under study.

For some interviewees, exposure to the 'religious other' had happened earlier in life:

'Gateshead at the time [mid-1940s] was a multi-religious community, with a large Hassidic Jewish community ... I was always used to having friends who were Jewish. I'd cycle to Marsden for a dip in the sea, and you'd pass the Mosque on the way ... world religions have always been a part of my life, certainly since adolescence. ${ }^{64}$

\footnotetext{
${ }^{59}$ Interview with Alan Loosemore, 25 March 2010.

${ }^{60}$ Interview with Julie Grove, 7 May 2010.

${ }^{61}$ Interview with Cecil Knight, 21 January 2010, emphasis added.

${ }^{62}$ See Edward Said, Orientalism (London: Penguin, 1978). Also, Ian Grosvenor, Assimilating Identities: Racism and Educational Policy in Post 1945 Britain (London: Lawrence and Wishart, 1997).

${ }^{63}$ Freathy, Parker, Schweitzer and Simojoki, 'Towards international comparative research on the professionalization of Religious Education'.

${ }^{64}$ Interview with Geoff Robson, 15 Oct 2010.
} 
Additionally, in our data, we see teachers' responses to uncertain times and to wider discourses about the marginalization of their subject. This led many of those interviewed to later pursue a commitment to the subject with great energy and zeal. Through archive-based research, we are aware of the on-going discussions about the place of RE in the school, ${ }^{65}$ the shortage of subject specialists, and a general sense of marginalization. ${ }^{66}$ Our interviewees confirmed the impact of this on a personal level: religious educators regularly felt that RE was best described as 'a Cinderella subject', with a division between 'experts' and 'grassroots people [who] were beleaguered and undervalued'. One interviewee recalled that:

'You never knew which posts would be cut; [RE] had expanded but we didn't know whether it was going to contract. RE teachers wanted more training but you didn't know what budget there would be ... There was less room for the radical, imaginative creative stuff. ${ }^{67}$

Whilst another recollected that 'In the secondary schools there was too much teaching RE by timetable; ... although you are a woodwork teacher, there is some RE that needs to be taught'. ${ }^{68}$

By using oral life history to open a window into the world of RE, various facets of the area of professional identity and practice become visible, enabling us to understand practice in the RE classroom (and the preoccupations and concerns of practitioners) in ways that are virtually impossible when restricted to archival sources. For example, within a context where many 'teachers felt that they hadn't got the materials [they needed] and the textbooks publishers were providing were irrelevant', we were told about the introduction of a range of multi-media resources, in contrast to 'school[s] whose RE equipment consisted of a pile of dusty Authorised Version Bibles in a cupboard' ${ }^{69}$ The move from purple-inked stencil duplicators to photocopiers, the use of $16 \mathrm{~mm}$ projectors to watch a wide variety of film strips, and the purchase, at the teacher's own expense, of a reel-to-reel tape recorder all increased the number of directions in which RE lessons could develop. The use of audio equipment, for example, allowed one teacher to 'record a lot of interesting stuff on radio; stuff on mind changing drugs which I used in class and also for drama, ${ }^{70}$ whilst another introduced songs by The Beatles as catalysts for discussion, on one occasion using 'She's Leaving Home' as a link to the Prodigal Son story. ${ }^{71}$ These examples of curriculum-in-use evidence the restricted vision provided through the vista of the formal curriculum.

Thus, our interviews reveal a complex melange of issues relating to teacher's professional identity and practice, from internal ideological tensions, to the type of classroom technology available.

\section{Curriculum development}

\footnotetext{
${ }^{65}$ Freathy and Parker, 'Secularists, Humanists and religious education'.

${ }^{66}$ For example, H. Marratt, Recruitment, Employment and Training of Teachers of Religious Education (London: British Council of Churches, 1971); Department of Education and Science, Survey of Religious Education in Secondary Schools in Lancashire. Confidential Report by H.M. Inspectors, DS38/78 (London: Department of Education and Science, 1973).

${ }^{67}$ Interview with Margaret Halsey, 18 April 2013.

${ }^{68}$ Interview with Geoff Robson, 15 October 2010.

${ }^{69}$ Interview with Geoff Robson, 15 October 2010.

${ }^{70}$ Interview with Cecil Knight, 21 January 2010.

${ }^{71}$ Interview with Geoff Robson, 15 October 2010.
} 
Another area of the world of RE revealed through the window of oral life history interviews was curriculum development. In this regard, oral life history has the potential to yield insights that fundamentally overthrow or undermine the existing historiography. However, in our case, this potential was not realised; rather our findings generated different perspectives on this historiography. For instance, a number of authors have written about the history of RE Agreed Syllabuses (The 1944 Education Act, prescribed that in county schools, Religious Instruction was to be defined by an Agreed Syllabus prepared or adopted by a local conference consisting of four committees which represented religious denominations, the Church of England, teacher associations and the LEA. These committees had to reach unanimous agreement before the Agreed Syllabus could be adopted by the LEA) ${ }^{72}$. However, their analyses have been restricted to the final published document. ${ }^{73}$ Through oral life history, it is possible to see what it was like to be a participant in the processes which led to the formation of the Committees and Syllabuses. Consequently, we begin to move away from a sanitized version of history, which foregrounds the resultant agreements and public statements of unity. Instead we can become more attentive to the messiness of Agreed Syllabus Committee politics and processes; the power dynamics and tensions between different groups and individuals; and the widening of the constituency of stakeholders to include representatives from non-Christian faith communities. Thereby, we become better able to see how the political and administrative processes interacted with the personal in curriculum history. Here we concentrate on three facets.

As we have argued elsewhere, Agreed Syllabus documents are often more aspirational than representative of classroom practice. ${ }^{74}$ The type of data revealed by our oral life history interviews helps us develop a clearer picture of the actualities of the situations within which Agreed Syllabuses were formulated, not least the discrepancies between legal obligations and local practices. Further, the data also helps us develop a better understanding of the processes that operate between the different levels of the curriculum. ${ }^{75}$ For example, one interviewee reported that 'there was no requirement that I followed the [Agreed] syllabus [but was encouraged to] devise a syllabus of my own making, ${ }^{76}$ whilst another states:

'I was completely ignorant of the structure ... in those days you closed your door and did what you wanted. ... It was a revelation to me that RE was determined by people locally., ${ }^{, 77}$

\footnotetext{
${ }^{72}$ See Education Act 1944, 7 \& 8 GEO. 6. Chapter 31, Part II, Section 29(4) and Fifth Schedule, (London: HMSO), [http://www.legislation.gov.uk/ukpga/1944/31/pdfs/ukpga_19440031_en.pdf (accessed 18 August 2011).]

${ }^{73}$ Bell, Agreed Syllabuses of Religious Education; Jack Priestley, 'Agreed Syllabuses: Their History and Development in England and Wales 1944-2004'. In International Handbook of the Religious, Moral and Spiritual Dimensions in Education. Part 2., eds. M. de Souza, K. Engebretson, G. Durka, R. Jackson, and A. McGrady (Dordrecht: Springer, 2006): Ch. 70, 1001-1017; Doney, 'That would be an ecumenical matter'.

${ }^{74}$ Research over a period has shown than Agreed Syllabuses are not always implemented in practice, for example: University of Sheffield Institute of Education, Religious Education in Secondary Schools (London: Thomas Nelson and Sons Ltd, 1961); Parker and Freathy, 'Context, complexity and contestation'.

${ }^{75}$ See above discussion of Labaree, 'The chronic failure of curriculum reform'.

${ }^{76}$ Interview with Ian Birnie, 4 April 2013.

${ }^{77}$ Interview with Julie Grove, 7 May 2010.
} 
This was not just an issue at school level; a newly qualified teacher described his request to the Local Education Authority (LEA) 'for a copy of the Agreed Syllabus that I should teach ... they were shocked when I explained that they published it' ${ }^{78}$ Another depicted the preference of the Chief Advisor in his local authority to use an 'alternative syllabus. [He] thought nothing of the syllabus that the agreed syllabus conference had drawn up'. ${ }^{79}$ Beyond this non-adoption of an Agreed Syllabus, there is also some evidence of a reluctance to revise the documents:

'I was told at interview [for post of LEA Advisor] by the Director of Education: "I will back you, but you are not to suggest that we change the Agreed Syllabus because the experience of adopting the [current] Syllabus was an incredible shock to me, I have never known so many backwards people come out of the woodwork. It was appalling. ... I am not going through the process of revision. Once bitten, twice shy.", 80

Many of the interviewees had been involved in the development and implementation of Agreed Syllabuses, and were very candid in their disclosures. It is clear that Agreed Syllabus Committees were not always harmonious gatherings. Tensions were witnessed and recounted to us in interview, as were power struggles between individual personalities keen to make their mark on the new syllabuses. One interviewee recalls his first visit to a group he had been invited to lead:

'[he] was overtly hostile ... How dare the authority bring this person in to drive our [work] ... Keep Out!! He eventually threw his toys out of the pram and withdrew. ${ }^{81}$

These were clearly not isolated occurrences; the same interviewee, recalling a conversation with a different character, recalled:

'[He said to me] "your great strength was that you came and you listened to these fierce debates and arguments ... people would get up and walk out, they would say the most outrageous things, you used to sit and listen and out of all this you used to come back the next week with something coherent, beautifully written, rational, and you had disentangled all the threads and so we found ourselves able to say yes, that is what we are probably after". ${ }^{82}$

We are also able to begin to consider the motivations that lay beneath some of these outbursts. A number of interviewees recall an outspoken, and at times volatile, colleague;

'His role was interesting, [it] was constantly to challenge us on the issue of whether we weren't reverting to the old Christian nurturing model of education ... [he] fulfilled his role. ${ }^{83}$

I remember him upsetting a primary teacher once who had worked very hard; she got up and walked out of the room in tears. He had these outbursts, and [the chairman] said to him quietly afterwards, "I think you need to go and

\footnotetext{
${ }^{78}$ Interview with John Hull, 26 March, 2010.

${ }^{79}$ Interview with Ian Birnie, 4 April 2013.

${ }^{80}$ Interview with Ian Wragg, 5 April 2013.

${ }^{81}$ Interview with Cecil Knight, 21 January 2010.

${ }^{82}$ Interview with Cecil Knight, 21 January 2010.

${ }^{83}$ Interview with Cecil Knight, 21 January 2010.
} 
apologize". [He] looked a bit like a naughty boy ... he went out ... it was a big thing for $[$ him $] .{ }^{84}$

[His] aggression did not come from ... it wasn't a negative sort of aggression, it was an impatience with the closed minds of other people and this passion for truth and openness and fairness. Once you had recognized that in [him] you could live with him ... he did get up some people's noses, and he could be very rude. $^{85}$

He was our biggest problem and our principal resource. ${ }^{, 86}$

The candour of these interviewees contrasts with the official rhetoric in government policy and local Agreed Syllabus documentation. Oral life history interviews reveal a level of debate and tension that is imperceptible in the published and archival evidence regarding Agreed Syllabuses. Historically, we want to know what the disagreements were and between whom. Oral life history enables us to get beneath the surface of the human interaction and political negotiation that form the discussions necessary to reach the agreement implied by the title of Agreed Syllabus. Through the information offered by our interviewees it becomes possible to begin to map these discussions in meaningful ways. For example, from documentary sources alone it is difficult to elicit the variety of ways in which it was attempted to ensure a range of religious traditions was represented on Agreed Syllabus Committees. In developing religiously-representative Agreed Syllabus content, 'one of the problems was the attempt (made quite fairly), to allow the religious groups to say what they thought should be taught about their particular faiths' ${ }^{87}$ During the earlier years of such attempts, in the $1960 \mathrm{~s}$, the emphasis appears to have been on ensuring that Agreed Syllabuses were 'accurate'. One interviewee describes the development of the 1966 Agreed Syllabus for West Riding, ${ }^{88}$ highlighting particularly the section on Jewish Children and their religion:

'We had help from a lecturer in Education at Leeds University. He was a tremendous help, he had produced a number of books, his particular interest was Judaism. ${ }^{89}$

The passing of the 1988 Education Reform Act formalised procedures for including representatives of non-Christian traditions on Agreed Syllabus Committees, although the practice had been well established for some years before. ${ }^{90}$ One interviewee described in detail the different responses to his attempts to include such groups before such formal procedures were in place:

${ }^{84}$ Interview with Cecil Knight, 21 January 2010.

${ }^{85}$ Interview with Cecil Knight, 21 January 2010.

${ }^{86}$ Interview with John Hull, 26 March 2010.

${ }^{87}$ Interview with Geoff Robson, 15 Oct 2010.

${ }^{88}$ West Riding Education Committee, Suggestions for Religious Education: West Riding Agreed Syllabus (Wakefield: West Riding Education Committee, 1966).

${ }^{89}$ Interview with Alan Loosemore, 25 March 2010.

${ }^{90}$ Great Britain. Education Reform Act 1988: Elizabeth II. Chapter 40 (London: The Stationery Office, 1989). Guidance issued in the 1970s specifically permits the 'inclusion of representatives of these religions on the Statutory Conference that draws up the syllabus'. Under this guidance, the term 'denomination', previously understood as a sub-grouping of the Christian church, was now 'seen as capable of bearing the wider meaning of representatives from non-Christian faiths' ('Religious Education in the Schools of England and Wales', HMI Memo to Inspectors 3/75, issued by Her Majesty's Inspector of Schools, January 1975. The National Archive (TNA) ED 135-35 HMI Memos 1975). See also Parker and Freathy, 'Context, complexity and contestation'. 
'For the Muslims there were 110 Mosques, and as we approached the Agreed Syllabus revision we wanted to franchise the Muslims, Hindus and Buddhists. I chose to go around addressing public meetings to encourage [Muslims] to get involved in the design of the new syllabuses. I explained that I had no one to speak to on their behalf. [I asked] if [they] could form some sort of representative organization ... two weeks later ... they set up the Lancashire council of mosques. The Hindus didn't want to do that; they understood that I needed some kind of structure [so] they directed me to the Preston Hindu Temple; they nominated people in the Temple to be their representatives, rather than form a county wide [structure]; same with Buddhist and Jewish. ${ }^{91}$

We also see that the desire to ensure that the non-Christian representatives were heard could result in tensions within the Christian groupings:

'Often the Free churches [who, when combined with other faiths, had only one vote between them] lost their voice because they wanted the Hindu or the Muslim to be heard. The Church of England would dominate the Agreed Syllabus committee and then after it was agreed, turn around and use their own thing anyway. 92

Such historical details of the workings of Agreed Syllabus Conferences would be barely possible without the access provided by oral life history. Amongst other things, it becomes possible to start exploring the mechanics by which one level of the curriculum (the formal curriculum) interfaces with others (the rhetorical and the curriculum-in-use) ${ }^{93}$ Further, this reveals what it might have meant to be a participant in a history that has already been told; in this case, the micro-political history of curriculum formation.

\section{Professional organizations}

Lastly, through the window of oral life history we are granted a fuller view of the political landscape of $\mathrm{RE}$ and within it the role of professional organizations. Alongside curriculum development, as discussed above, the existing historiography is also predicated on the history of individual organizations and institutions. Much of the archive material used for these histories is of a 'vertical' nature, focusing almost entirely on the organization itself. Even where materials relate to relationships with other organizations and institutions, the viewpoint is generally that of the originating institution. In contrast, oral life history expedites 'horizontal' work; it facilitates a visualization of the terrain that lies between institutions, revealing how they inter-relate, the power struggles and competition between them.

Here we restrict our discussions to the Christian Education Movement (CEM), with whom many of our interviewees had worked or had contact in some capacity. The history and role of CEM is described elsewhere. ${ }^{94} \mathrm{We}$ identify four particular facets where the oral life history approach has allowed us a clearer perspective on this history.

Firstly, we are able to envisage the relationships between institutions and government. 'Off the record' discussions and consultations, by their nature, are absent from the documentary sources, of both

\footnotetext{
${ }^{91}$ Interview with Ian Birnie, 4 April 2013.

${ }^{92}$ Interview with John Sutcliffe, 5 March 2013.

${ }^{93}$ Labaree, 'The chronic failure of curriculum reform'.

${ }^{94}$ Parker et al., 'The Professionalisation of Non-Denominational Religious Education in England: politics, organisation and knowledge'.
} 
individual organizations and governmental departments. Some of our interviewees, having been involved in such discussions, problematized the existing 'view', not just in terms of what was discussed, but in terms of the consequences of such associations. For example, one interviewee recalls an attempt at governmental interference:

'We wanted [this lady] to serve on [a CEM] Research Committee, through which we were able to access some government funding. It was all agreed ... but [she was linked to] St Martin's [which] had a Moral Education project going on at the time, which the Conservative government did not like. The morning after we had elected her ... a political advisor to the Secretary of State at the Department of Education [telephoned] saying that they really didn't think it was a very good idea, and would we like to change our minds about it? Well we didn't change our minds. We were a totally independent body. ${ }^{, 95}$

Secondly, we are able to plot the relationships and tensions between organizations, particularly the way in which CEM responded to the emergence of new groups. In this regard the archive material tends to be rather guarded. Details can be found about what was finally resolved, but the process by which such resolution comes about tends to be hidden; our oral life history interviews can make visible otherwise unclear situations. For instance, much of the information shared with us foregrounded the efforts made by CEM to maintain its dominant position in the field, and suggesting that CEM felt under threat as a result of the emergence of a number of groups during our period of our interest. These included the National Association of Teachers of Religious Knowledge (NATORK), founded under the leadership of Miss Howlett in 1968, ${ }^{96}$ the Association of Religious Education (ARE, est. 1968), the Religious Education Council of England and Wales (est. 1973), and the Association of Christian Teachers (ACT, est. 1971). To illustrate, CEM attempted to 'stop [ACT] coming into existence', feeling that the establishment of ACT 'was going to be deleterious' and was a cause of 'genuine worry' prompting a resurgence of effort by the CEM teacher's committee:

'As soon as $[\mathrm{ACT}]$ came into existence, $[\mathrm{CEM}]$ suddenly took off, doing all sorts of things it hadn't been doing before, perhaps trying to demonstrate that CEM was THE teachers association for RE teachers. It had national support from Council of Churches, etc, and a long, long history of involvement in education in general through ICE and SCMS to pre-war years. ${ }^{97}$

Similar efforts to prevent the establishment of 'rival' groups were divulged in the discussion of other organisations. In respect of the development of ARE, we were told that the group was 'seen to be a bit of a threat to CEM, a strange, almost schizophrenic, split [arose] in CEM because of that' ${ }^{98}$ With regard to ARE and NATORK, it was stated:

'It became rather complicated. As well as being professional bodies ... they were of a more evangelical foundation. Eventually we mopped them both up. I don't mean that unkindly, they did become - after lots of negotiation - the professional part of CEM. It wasn't a matter of trying to sheep steal, but it was

\footnotetext{
${ }^{95}$ Interview with John Sutcliffe, 5 March 2013.

${ }^{96}$ On Miss Howlett see: Parker and Freathy, 'Ethnic Diversity, Christian Hegemony'; Freathy et al., 'Raiders of the Lost Archives'; Parker et al., 'The Professionalisation of Non-Denominational Religious Education in England'.

${ }^{97}$ Interview with Peter Lefroy-Owen, 29 May 2012.

${ }^{98}$ Interview with Bob Langley, 19 April 2013.
} 
about drawing together resources for $\mathrm{RE}$ so that when we went to the Government we could say that by and large we represent the RE community. 99

In contrast, activists involved in the establishment of ARE saw it fulfilling a different role from CEM:

'We regarded ourselves as parallel, not trying to duplicate what CEM were doing ... but more a representative group for RE teachers to deal with LEAs. Part of the motivation for ARE, not that we thought it at the time, was to try to have a genuinely neutral body that did not discuss theology, but did discuss teaching, and could contain within it people of quite different viewpoints, but had in common that they were professionally trained and practicing $\mathrm{RE}$ teachers. $^{100}$

Those involved in these events report that, unbeknown to those opposed to the establishment of ARE, their efforts:

'stirred up a great deal of antagonism that added to our burden enormously; we kept getting fairly high level pressure being put on us from the Federation of Free Churches ... also from [a] Professor of Education and others. At the second meeting, [he] stood up and said he had copies of ten letters from influential people saying that this association should not be formed. He had been sent as a delegate to try and stop this organization coming into existence so we did have forewarning that there was a problem brewing, but we didn't know the extent of it at that time ... There were concerted efforts to try and stop ARE being formed at all at quite a high level. This came from CEM. ${ }^{, 101}$

The interactions revealed by our interviewees range beyond inter-group tensions. Accounts of the first meeting of NATORK, for instance, demonstrate the extent to which some houses were divided within themselves. One interviewee recounted his role in this subterfuge and politicking. At the first meeting of NATORK, the agenda tabled by Miss Howlett (chair), was supplanted by an alternative agenda of his devising, circulated to the committee, but not to Miss Howlett. This alternative was tabled on the basis that hers might lead to the establishment of a group that:

'would not be along the lines of a professional association, but more a defence and attack committee on behalf of the 1944 settlement for the teaching of RE in schools and the act of worship. ${ }^{102}$

He went on to report:

'We had a general discussion. Miss Howlett felt that it was slipping out of her grasp and going in a direction she hadn't envisaged. She was very pleasant and apologized and said she should withdraw and continue with what her vision was. ${ }^{103}$

\footnotetext{
${ }^{99}$ Interview with John Sutcliffe, 5 March 2013.

${ }^{100}$ Interview with Peter Lefroy-Owen, 29 May 2012.

${ }^{101}$ Interview with Peter Lefroy-Owen, 29 May 2012.

${ }^{102}$ Interview with Peter Lefroy-Owen, 29 May 2012.

${ }^{103}$ Interview with Peter Lefroy-Owen, 29 May 2012.
} 
Such internal wrangling seen from an individual perspective begs questions about the operationalized, perhaps even gender-based, power differentials amongst and across groupings of religious educators, and provides a critical dimension that is not always (if ever) evident in the existing historiography and which may only have become evident through oral life history.

The findings presented above represent an initial analysis of the existing data. As such they have provoked a series of methodological reflections which need to be considered prior to any further and subsequent analysis of the same data set or, indeed, the collection of further data. We recognize that we could have applied any one (or more) of an array of interpretative frameworks. For example, a poststructural framework could have be applied to the interview data allowing exploration of agency and subjectivity; ${ }^{104}$ an approach centring on individual learning journeys could have be employed; ${ }^{105}$ or an approach linking biography with an author's theoretical framework and identity formation. ${ }^{106}$ Similarly, political interpretations focusing on stakeholders and pressure groups, ${ }^{107}$ or approaches relating to generational studies could all have been applied. ${ }^{108}$ The rich data that we have gathered can - and we hope will — be appraised and discussed from a variety of perspectives, highlighting the fact that the method is not limited to one paradigmatic approach. ${ }^{109}$

In the section that follows, we focus briefly on some of the methodological matters that this work has raised for us, considering the issues of historical truth; the nature of memory/memories; the relationship between past and present; and the implications of these reflections for oral life history practice, particularly in terms of whose story we are attempting to narrate.

\section{Methodological reflections}

Our experience leads us to concur with Philip Gardner, ${ }^{110}$ in regarding historical 'truth' as being dynamic, open to multiple (and, arguably, equally valid) interpretations. Likewise, as Mikhail Bakhtin observes, historiography is unfinalizable; ${ }^{111}$ as new evidence emerges (or is generated, in the case of

\footnotetext{
${ }^{104}$ See, for example, Michael L. Fitzhugh and William H. Leckie Jr., 'Agency, Postmodernism, and the Causes of Change', History and Theory, Theme Issue 40 (2001): 59-81; Deborah Youdell, 'Subjectivation and Performance Politics - Butler Thinking Althusser and Foucault: Intelligibility, Agency and the Raced-nationed-religioned Subjects of Education', British Journal of Sociology of Education, 27, no. 4 (2006): 511-528.

${ }^{105}$ For example, Jacobs et al., 'Learning lives and alumni voices'; Andrea Jacobs and Camilla Leach, 'Teacher training and the public good: the University of Winchester Alumni Project', History of Education 40, no. 2 (2011): 213-28.

${ }^{106}$ For example: Avest, 'On the Edge'; Kuhn, 'Family Secrets'.

${ }^{107}$ For example: Bethany L. Rogers 'Teaching and Social Reform in the 1960s: Lessons From National Teacher Corps Oral Histories', Oral History Review 35, no. 1 (2008): 39-67.

${ }^{108}$ For example: Peter Ester, "It Was Very, Very Churchy": Recollections of Older Dutch-Americans on Growing Up in Holland, Michigan', The Oral History Review 35, no. 2 (2008): 117-138; Ian Jones, The Local Church and Generational Change in Birmingham, 1945-2000. (Woodbridge: Boydell \& Brewer Ltd, 2012).

${ }^{109}$ For a discussion of one critical, multi-perspectival and mixed-methods 'bricolage' approach, see: Rob Freathy, Stephen Parker and Jonathan Doney. 'Raiders of the Lost Archives: Searching for the Hidden History of Religious Education in England', in History, Remembrance and Religious Education, eds. S. G. Parker, R. Freathy and L. J. Francis (Oxford: Peter Lang, 2014): 1-19.

${ }^{110}$ Philip Gardner, Hermeneutics, History and Memory (Abingdon: Routledge, 2010).

${ }^{111}$ Mikhail Bakhtin, Problems of Dostoevsky's Poetics (Minneapolis: University of Mineapolis Press, 1984): 166.
} 
oral life histories) revisions to the historiography become necessary. In partnership with written documentary evidence, such co-constructed oral life histories as sources of evidence, validate individual biography and agency as part of the historical record. This co-construction (between interviewer and interviewee) underlines that history has multiple voices (heteroglossia). When extended to the relationship between spoken sources and written sources (both 'transcriptions' of spoken sources and those written temporally nearer the events being described), this multiplicity of tongues is even more pronounced. ${ }^{112}$

In our consideration of the issue of memory/memories, we have become even more aware than when we began, that the reconstruction of memories is a complex field. We sense a burden of responsibility upon our shoulders to be as mindful of the circumstances under which our oral sources are produced, and the audience for which they are rehearsed, as we are when working with documentary archive materials. ${ }^{113} \mathrm{We}$ find a significant discussion about restructuring and reordering memories within the wider literature. ${ }^{114}$ For example, Jens Brockmeier refers to memory as 'the warehouse of the past', ${ }^{115}$ a construction that suggests, we believe, that 'biographical talk will be consistent from one telling to another because the same memory is being retrieved'. ${ }^{116}$ In contrast, through ongoing processes of restructuring and reordering, on both conscious and sub-conscious levels, we sense that the oral testimonies gathered here are subject to a redrafting process in similar ways to written sources, ${ }^{117}$ whether through

the repetitions, representations and commemorations of collective memory or through the more specific moment of recollection where a seldom visited corner of memory is suddenly recalled with a timeless immediacy, often evoking statements such as 'I can see it now'. 11

Whilst many of these issues are as pertinent to documentary research, we continue to strive for a better understanding of the relationships between memories of events and historical events themselves, something which is unclear and which varies between individuals, ${ }^{119}$ being affected by factors such as age, and the interval between the event and the recall of it. ${ }^{120}$ Further, the extent to which interviewees' recollection of 'curriculum-in-use' is affected by their recollections of the 'official' curriculum is a complex issue. We reminded ourselves frequently, and now remind the reader, that we have not

\footnotetext{
${ }^{112}$ For discussion of the relationship between spoken sources and the written records of them, see Philip Gardner and Peter Cunningham, 'Oral History and Teachers' Professional Practice: a wartime turning point?', Cambridge Journal of Education 27, no. 3 (1997): 331-42.

${ }^{113}$ Gardner and Cunningham, 'Oral History and Teachers' Professional Practice'.

${ }^{114}$ Popular Memory Group, 'Popular memory: theory, politics, method', in Making Histories: studies in history-writing and politics, eds. R. Johnson et al. (London; Hutchinson, 1982): 205-252.

115 Jens Brockmeier, 'Remembering and forgetting: narrative as cultural memory'. Culture \& Psychology 8, no. 1 (2002): 15-43, 17.

${ }^{116}$ Taylor, 'One participant said ...', 392.

${ }^{117}$ Gardner and Cunningham, 'Oral History and Teachers' Professional Practice'.

${ }^{118}$ Popular Memory Group, 'Popular memory', 339.

${ }^{119}$ M. Stephenson, 'Timeless projects: remembering and voice in the history of education', History of Education Review 37, no. 2 (2008): 3-14; E. Domanska, 'Frank Ankersmit: from narrative to experience', Rethinking History 13, no. 2 (2009): 175-195; Jacobs et al., 'Learning lives and alumni voices'.

${ }^{120}$ Peter Coleman, 'Ageing and life history: the meaning of reminiscence in late life'. In S. Dex (ed), Life and Work. History Analyses: Qualitative and Quantitative Developments (London: Routledge, 1991): 120-43.
} 
collected verbatim accounts of exactly what happened in the past, but rather, we have gathered present reconstructions of past events: ${ }^{121}$ 'However much [interview data] proclaim the past to us, they originate in the present, as the reflections of [interviewees] recalling distant experiences'. ${ }^{122}$ Here we find informative the Indigenous Australian comprehension of what we call 'history' being understood as 'remembering'. 123

We thus accept that oral life history accounts should not be interpreted: simply as evidence, which places the historian in the role of expert, nor as literature, which makes them marginal for history's purpose of establishing what happened in the past, but as contributions to historiography in their own right. ${ }^{124}$

We have also been prompted to reflect on the relationships between the 'past' and the 'present'. Gary McCulloch suggests that an accurate historical map is essential for the development of an 'historical framework in which to locate and judge current educational policies', ${ }^{125}$ enabling the historian to be in a position to 'address contemporary educational problems', ${ }^{126}$ he describes this as the 'useable past'. ${ }^{127}$ Our experience, particularly our reflections on the nature of memory as 'present remembering', leads us to suggest an extension to McCulloch's notion; we agree with the principle that current debates must be informed by history, and find the notion of 'history as present' to be helpful. ${ }^{128}$ with a realisation that history is written in, and for, the present.

The implications for the practice of oral life history research are far reaching. In discussing our project with colleagues, there has been much deliberation about the validity of data gathered through interviews. We note that interviews can produce 'apparently inconsistent or contradictory accounts ${ }^{, 29}$ whereby 'subjects sometimes act up ... adopt different masks [and] forge their own signatures' ${ }^{130}$ Interviewees can 'deflect researchers' agendas', ${ }^{131}$ perhaps because concerns are not always shared, nor understandings of when a particular period begins and ends. ${ }^{132}$ Interviews are never 'pure' and free from

${ }^{121}$ McLeod and Thomson, Researching social change.

${ }^{122}$ Gardner and Cunningham, 'Oral History and Teachers' Professional Practice', 338.

${ }^{123}$ John Bradley, Phillip Adgemis, and Luka Haralampou, "Why Can't They Put Their Names?": Colonial Photography, Repatriation and Social Memory', History and Anthropology 25, no.1 (2013): 47-71.

${ }^{124}$ R. Kennedy, 'Stolen Generations testimony, trauma, historiography, and the question of "truth", Aboriginal History 25 (2001): 116-131, 117.

${ }^{125}$ Gary McCulloch, The struggle for the history of education (London: Routledge, 2011): 59.

${ }^{126} \mathrm{McCulloch}$, The struggle for the history of education; W. Robinson, 'The struggle for the history of education, by Gary McCulloch - review 3'. History of Education 41, no. 5 (September 2012): 706-7.

${ }^{127} \mathrm{McCulloch}$, The struggle for the history of education, 58. McCulloch's approach does not find universal support; see for example Robinson, The struggle for the history of education.

${ }^{128}$ See, for example, Walter Benjamin, Theses on the Philosophy of History. (New York: Illuminations, 1968); Ian Iyne, The Temporality of Language: Kant's Legacy in the Work of Martin Heidegger and Walter Benjamin. (Unpublished PhD Thesis, Warwick University, 1995)

${ }^{129}$ Watson, Unreliable narrators?, 370.

${ }^{130}$ Maggie McLure, Discourse in Educational and Social Research (Buckingham: Open University Press, 2003): 171.

${ }^{131}$ McLure, Discourse in Educational and Social Research, 171.

${ }^{132}$ See Gardner and Cunningham, 'Oral History and Teachers' Professional Practice'. 
interviewer influence, ${ }^{133}$ and are best considered a process by which ' $[\mathrm{t}]$ he interviewer and respondent collaborate in the construction of a narrative'. ${ }^{134}$

We have used historical enquiry here, in part, to develop a more nuanced understanding of the historical period in which contemporary RE was formed, particularly the processes and pressures involved. This in turn offers potential to illuminate present discussions centring on the marginalization of RE, the confusion over the nature and purpose of the subject, gaps in training for those teaching the subject and the impact of wider education policy on RE. ${ }^{135}$ Each of these current issues has an historical background and context, an accurate awareness of which potentially enriches present discussions. In particular we believe that an historical understanding of how contemporary RE theories, policies and practices have developed can illuminate longer-term, broader and philosophical issues, add depth and range to our understanding of the present, temper a tendency to see contemporary challenges as entirely novel, ${ }^{136}$ and provide us with hope: '[t]here is, perhaps, no more liberating influence than the knowledge that things have not always been as they are and need not remain so'. ${ }^{137}$

\section{Conclusion}

In this paper we have demonstrated that oral life history can be used to enrich the historiography of RE; in doing so, we have established its potential to enrich the history of education more generally. By opening a new window into the world of RE, oral life history has shown its potential to reveal (from the point of view of the actors involved) things that were otherwise hidden, give new insights, and capture processes, debates, and practices that documentary sources alone cannot. Specifically, we have highlighted three areas in which oral life history enriches the historiography of English RE: professional identity and practice, curriculum development, and professional organizations. Even our brief recounting of the content of identified interview themes shows how the method can illuminate and detail the operational dynamics of RE at an (inter-)personal and organizational level. The method has revealed matters that have been marginal to, or excluded from, the historical record, providing insights into areas which other types of source cannot, and confirming and contrasting with knowledge that has been gleaned from primary published and unpublished documentary sources. Moreover, analysis of our interviews reveals, at a personal level, how the significant changes made to the RE curriculum, at a time of demonstrable social (including religious) change, impacted upon a cohort of religious educationalists (who later became leaders in the field), serving to shape their faith and professional identity at an intimate level. In short, the collected personal, religious and professional narrative accounts represented by our interviews enrich our understanding of the changes occurring within RE over a sustained period, adding a human dimension to the historiography.

${ }^{133}$ J. Powney, and M. Watts, Interviewing in Educational Research (London: Routledge, 1987); T. Rapley, 'The Art(fulness) of Open-ended Interviews: Some Consideration on Analysing Interviews', Qualitative Research 1, no. 3 (2001): 303-23; Watson, Unreliable narrators?.

${ }^{134}$ Jacobs et al., 'Learning lives and alumni voices', 220.

${ }^{135}$ Ofsted, Religious Education - Realising the Potential (Manchester: Ofsted, 2013); All Party Parliamentary Group for Religious Education, RE: The Truth Unmasked: The Supply of and Support for Religious Education Teachers (London: All Party Parliamentary Group for Religious Education and The Religious Education Council of England and Wales, 2013).

${ }^{136}$ Freathy and Parker, 'The necessity of historical inquiry in educational research: The case of Religious Education'.

${ }^{137}$ Brian Simon, 'The History of education'. In The study of education, ed. J. W. Tibble (London: Routledge and Kegan Paul, 1966): 91-131, 92. 
Further, we have also demonstrated, by relating the method to some underpinning theoretical foundations, that the approach is methodologically robust. We have foregrounded the importance of methodological clarity and attentiveness to ethical issues; highlighted issues relating to the dynamic nature of historical 'truth'; and emphasized the complex relationship between events, memories and the reconstruction of the past in the present, and reflected on the role of the researcher in the retelling of other's narratives.

This exploratory project has demonstrated the potential of oral life history to expose things that were previously hidden, thus allowing us to chart new territories and map familiar terrains in innovative ways. With this topography now exposed, we can consider undertaking more detailed and focused research in particular areas. From the initial analysis of the interviews, it is clear that there are a number of areas for further work. For example, current debates around issues of contemporary importance can all be informed by having a more detailed and nuanced understanding of how they have been dealt with historically, for example, the interaction between personal beliefs and values and professional identity and practice; issues of professional development and professional status; recruitment, training and retention of teachers; issues relating to implementation of curriculum change; and relationships between professionals and practitioners and other stakeholders.

For many of our interviewees, their memories live on in their own minds, they have influenced and continue to influence the thinking of others. The stories religious educationalists tell about their personal and professional lives affect the nature and purpose of the subject in the present, the way the profession organizes and develops itself, and so on. This history is not dead and buried, but living with us now. Our work tells us about the past in the present and the affect that it has. Beyond these issues, there is also considerable potential for further work in developing knowledge about how different groups have related to each other historically, perhaps informing present issues in terms of debates over the ownership of RE. ${ }^{138}$

\section{Acknowledgements}

This research was supported by The British Academy (Ref. SG-54151) and The Westhill Endowment Trust. The authors would also like to thank all the interviewees who participated.

\section{Notes on the contributors}

Jonathan Doney is a Research Fellow at the University of Exeter and an Associate Lecturer at the University of Winchester. His first degree was in Theological Studies (Bristol), and his Masters is in Educational Research (Exeter). His doctoral work, funded by the ESRC and supervised by Drs Rob Freathy and Deborah Osberg, centred on the interrogation of policy development in English RE, focusing on the relationships between the Ecumenical movement and the adoption of the study of world religions during the 1960s and 1970s, and his wider research interests are in methodological innovation, critical studies, and the role of education in developing identity. He is co-editor of History of Education Researcher.

Stephen Parker is Professor of the History of Religion and Education at the University of Worcester. He has authored and edited numerous books, book chapters and journal articles on the histories of religion and education and their intersections, including History, Remembrance and

\footnotetext{
${ }^{138}$ See, for example, Charles Clark and Linda Woodhead, A New Settlement: Religion and Belief in Schools, (Westminster Faith Debates. http://faithdebates.org.uk/wp-content/uploads/2015/06/A-NewSettlement-for-Religion-and-Belief-in-schools.pdf, accessed $10^{\text {th }}$ February 2016).
} 
Religious Education (Oxford, 2014) and the Bloomsbury Reader in Religion and Childhood (London, 2017). He is Editor of the Journal of Beliefs and Values, and lead Editor for the Peter Lang series on Religion, Education and Values. He is currently leading a Leverhulme Trust-funded project on religious educational broadcasting.

Rob Freathy is Associate Professor of History of Education at the University of Exeter. He has authored and edited numerous books, book chapters and journal articles on religious education, taking both historical and contemporary perspectives, including The Art of Bible Reading (Buxhall, 2014) and History, Remembrance and Religious Education (Oxford, 2014). He is Book Reviews Editor for History of Education, co-editor of History of Education Researcher and an Editorial Board member for the British Journal of Religious Education. He is currently directing a project on critical, dialogic and enquiry-based Religious Education funded by the Culham St. Gabriel's Trust. 